\title{
UJI AKTIVITAS ANTIOKSIDAN EKSTRAK ETANOL DAUN MANGGA KASTURI (Mangifera casturi Kosterm.)
}

\author{
Dwi Lestari ${ }^{1}$, Muthia Dewi MA ${ }^{2}$, Jati Pratiwi ${ }^{3}$, Lidya Handoko Saputri ${ }^{4}$ \\ ${ }^{1234}$ Universitas Muhammadiyah Kalimantan Timur, Samarinda \\ Email Korespondensi: d1792@umkt.ac.id
}

\begin{abstract}
ABSTRAK
Mangga kasturi (Mangifera casturi Kosterm.) merupakan salah satu tumbuhan di Indonesia yang memiliki potensi sebagai antioksidan. Tujuan penelitian ini adalah untuk mengetahui nilai $\mathrm{IC}_{50}$ dan potensi antioksidan ekstrak etanol daun mangga kasturi (Mangifera casturi Kosterm.). Ekstrak etanol daun mangga kasturi (Mangifera casturi Kosterm.) diekstraksi menggunakan maserasi dengan pelarut etanol $96 \%$. Uji aktivitas antioksidan dilakukan dengan metode DPPH (1,1-Difenil-2-Pikrilhidrazil) menggunakan spektrofotometer UV-Vis dan vitamin C sebagai pembanding. Berdasarkan hasil pengujian skrinning fitokimia pada ekstrak etanol menunjukan hasil metabolit sekunder yang positif seperti alkaloid, flavonoid, tanin dan kuinon. Hasil penelitian dari pengujian ekstrak etanol daun mangga kasturi (Mangifera casturi Kosterm.) dengan metode DPPH menunjukan bahwa ekstrak etanol memiliki aktivitas antioksidan dengan nilai $\mathrm{IC}_{50}$ sebesar 83,61 ppm dan termasuk dalam potensi antioksidan dengan kategori kuat.
\end{abstract}

Kata kunci : Mangifera casturi Kosterm., Daun, Mangga Kasturi, DPPH, $\mathrm{IC}_{50}$ 


\title{
ANTIOXIDANT ACTIVITY OF ETHANOL EXTRACT OF MANGGA KASTURI LEAVES (Mangifera casturi Kosterm.)
}

\begin{abstract}
Mangga Kasturi (Mangifera casturi Kosterm.) is one of the plants in Indonesia that has potential as an antioxidant. The purpose of this study was to determine the $I_{50}$ value and antioxidant potential of the ethanol extract of mangga kasturi leaves (Mangifera casturi Kosterm.). The ethanol extract of mangga kasturi leaves (Mangifera casturi Kosterm.) was extracted using maceration with $96 \%$ ethanol as solvent. The antioxidant activity test was carried out using the DPPH (1,1-Diphenyl-2-Picrylhydrazil) method using a $U V$-Vis spectrophotometer and vitamin $C$ as a comparison. The results of phytochemical screening tests on ethanol extracts showed positive secondary metabolites such as alkaloids, flavonoids, tannins, and quinones. Testing the ethanol extract of Mangga Kasturi leaves (Mangifera casturi Kosterm.) with the DPPH method showed that the ethanol extract had an antioxidant activity with an $I_{50}$ value of $83.61 \mathrm{ppm}$ in the strong category of antioxidant potential.
\end{abstract}

Keywords: Mangifera casturi Kosterm, Leaf, Mangga Kasturi, DPPH, IC $C_{50}$

PENDAHULUAN

Antioksidan berfungsi untuk menetralisir radikal bebas sehingga tubuh terlindungi dari berbagai macam penyakit degeneratif. Tubuh memerlukan antioksidan eksogen (antioksidan dari luar tubuh) untuk menghindari terjadinya paparan radikal bebas dikarenakan tubuh tidak mempunyai cadangan antioksidan dalam jumlah banyak. (Panjaitan, 2011)
Radikal bebas adalah molekul yamg mengandung satu atau lebih elektron tidak berpasangan pada orbital terluarnya dan bersifat reaktif. Suatu atom atau molekul akan tetap stabil bila elektronnya berpasangan, untuk mencapai kondisi stabil tersebut radikal bebas dapat menyerang bagian tubuh seperti sel sehingga dapat menyebabkan rusaknya sel tersebut dan berimbas pada kinerja sel, jaringan dan pada akhirnya pada proses 
metabolisme tubuh. Semakin banyak jumlah radikal bebas didalam tubuh akan semakin banyak sel yang rusak. Sel yang rusak dapat menyebabkan proses penuaan dengan cepat dan dapat menimbulkan kanker. (Rohmatussolihat, 2009)

Senyawa antioksidan yang dapat ditemukan pada tanaman, antara lain berasal dari golongan polifenol, bioflavonoid, vitamin $\mathrm{C}$, vitamin $\mathrm{E}$, betakaroten, dan katekin. (Nurmalasari et al., 2016)

Senyawa fenolik atau polifenolik antara lain dapat berupa golongan flavonoid. Memaparkan adanya aktivitas penangkap radikal dari ekstrak yang berkorelasi positif dengan kandungan senyawa fenolik dan sumbangan aktivitas dari senyawa flavonoidnya. Semakin tinggi kadar senyawa fenolik dan flavonoid maka aktivitas penangkap radikalnya semakin meningkat. (Sayuti \& Yenrina, 2015)

Tanaman mangga kasturi (Mangifera casturi) merupakan buah mangga khas dari Kalimantan. Dari beberapa penelitian sebelumnya tanaman buah mangga kasturi (Mangifera casturi) memiliki banyak kandungan senyawa metabolit sekunder seperti saponin, tanin, triterpenoid, flavonoid, dan fenolat yang dapat digunakan sebagai antibakteri dan antioksidan. (Rosyidah, 2010)

Dengan adanya zat kimia yang ada dalam buah mangga kasturi (Mangifera casturi) sebagai antioksidan maka peneliti tertarik untuk melakukan penelitian terhadap daun dari tanaman kasturi (Mangifera casturi). Tujuan penelitian ini adalah untuk melihat kandungan senyawa kimia yang terdapat pada ekstrak etanol daun mangga kasturi dan untuk melihat nilai Inhibitory Concentration 50 ( $\left.\mathrm{IC}_{50}\right)$ aktivitas antioksidan dengan metode peredaman DPPH dari ekstrak tersebut.

\section{METODE PENELITIAN MATERIAL}

Sampel yang digunakan dalam penelitian ini adalah daun mangga kasturi (Mangifera casturi Kosterm.) yang diperoleh dari Samarinda, Kalimantan Timur. Waktu panen diambil pada sore hari bertujuan agar proses fotosintesis pada tumbuhan telah sempurna.
Alat dan bahan
Bahan penelitian merupakan bahan- bahan yang diperlukan dan digunakan pada penelitian daun mangga kasturi, etanol 96\%, vitamin C, DPPH (1,1- difenil-2-pikrilhidrazil), air suling, serbuk Mg, Besi (III) Klorida, amil 
alkohol, asam klorida $2 \mathrm{~N}$ dan pereaksi Mayer.

Alat yang digunakan pada penelitian berupa seperangkat alat maserasi, alat gelas, kertas saring, corong kaca, botol vial, kuvet, kaca arloji, sarung tangan, cawan porselen, timbangan analitik, blender, aluminium foil, ayakan mesh 60 , batang pengaduk, mikropipet dan Spektrofotometri UV-Vis (Shimadzu UV1800).

\section{Rancangan Penelitian}

1. Determinasi tanaman

Determinasi bertujuan untuk memastikan kebenaran tumbuhan yang diteliti dan untuk menghindari terjadinya kesalahan dalam pengambilan bahan penelitian serta proses dalam menentukan nama dan jenis tumbuhan secara spesifik. Determinasi dilakukan di Laboratorium Ekologi Dan Konversasi Biodeversitas Hutan Tropis, Fakultas Kehutanan Universitas Mulawarman Samarinda.

2. Pembuatan simplisia

Daun yang telah dikumpulkan ditimbang sebanyak $6 \mathrm{~kg}$, dicuci di bawah air mengalir, ditiriskan dan disebarkan di atas kertas hingga airnya teresap. Sampel yang masih utuh dikeringkan dengan cara dianginanginkan di dalam ruangan yang terlindung dari sinar matahari secara langsung. Berat sampel yang diperlukan $2 \mathrm{~kg}$ pada simplisia dengan pengeringan. Simplisia yang telah kering kemudian dihaluskan menggunakan blender, diayak dengan menggunakan mesh 60. Disimpan pada wadah kaca dan disimpan di tempat yang terlindung dari sinar matahari secara langsung

3. Ekstraksi daun mangga kasturi (Mangifera casturi Kosterm.)

Sampel sebanyak $2 \mathrm{~kg}$ dimasukkan dalam tempat untuk maserasi menggunakan pelarut etanol $96 \%$ yang digunakan yaitu sebanyak $5 \mathrm{~L}$. Proses ekstraksi dihentikan, jika pelarut yang ada di dalam labu tidak bewarna atau berubah menjadi bening. Ekstrak yang diperoleh diuapkan diatas penangas air untuk memperoleh ekstrak etanol pekat.

\section{Skrining Fitokimia}

Skrining fitokimia dilakukan untuk mengetahui metabolit sekunder yang terkandung di dalam ekstrak etanol daun mangga kasturi (Mangifera casturi Kosterm.). Metabolit sekunder 
yang diuji secara kualitatif antara lain alkaloid, flavonoid, tanin, dan saponin.

a. Uji Alkaloid

Ekstrak etanol daun mangga kasturi (Mangifera casturi Kosterm.) sebanyak $5 \quad \mathrm{mg}$ ditimbang, ditambahkan $1 \mathrm{ml}$ $\mathrm{HCl} 2 \mathrm{~N}$ dan $9 \mathrm{ml}$ air suling, dipanaskan di atas penangas air selama 2 menit, didinginkan lalu disaring. Filtrat dipakai untuk percobaan berikut: 3 tetes filtrat, ditambahkan 2 tetes pereaksi Mayer reaksi positif ditandai dengan terbentuknya endapan menggumpal berwarna putih atau kuning. (Depkes RI, 1995)

b. Uji Flavonoid

Sejumlah ekstrak etanol daun mangga kasturi (Mangifera casturi Kosterm.) dilarutkan dalam etanol, sebanyak $1 \mathrm{ml}$ sampel ditambahkan 0,5 gram serbuk magnesium dan 10 tetes $\mathrm{HCl}$ pekat (pereaksi shinoda), bila bereaksi positif akan menghasilkan larutan berwarna jingga, merah muda atau merah. (Harborne, 1996)

c. Uji Tanin
Ekstrak etanol daun mangga kasturi (Mangifera casturi Kosterm.) sebanyak $5 \mathrm{mg}$ ditimbang, disari dengan $10 \mathrm{ml}$ air suling, disaring, filtrat diencerkan dengan air suling sampai tidak berwarna. Diambil $2 \mathrm{ml}$ larutan, ditambahkan 1 sampai 2 tetes pereaksi Besi(III) Klorida. Terjadi warna biru atau hijau kehitaman menunjukkan adanya senyawa tanin. (Harborne, 1996)

d. Uji Saponin

Ekstrak etanol daun mangga kasturi (Mangifera casturi) sebanyak $5 \mathrm{mg}$ ditimbang, dimasukkan dalam tabung reaksi, ditambahkan $10 \mathrm{ml}$ air suling panas, didinginkan, dikocok kuat-kuat selama 10 detik, terbentuk buih selama tidak kurang dari 10 menit setinggi 1$10 \mathrm{~cm}$, pada penambahan 1 tetes larutan $\mathrm{HCl} 2 \mathrm{~N}$, apabila buih tidak hilang menunjukkan adanya saponin. (Harborne, 1996)

e. Uji Steroid

Ekstrak etanol daun mangga kasturi (Mangifera casturi Kosterm.) dicampur dengan 
asetat anhidrat ditambah $\mathrm{H} 2 \mathrm{SO} 4$ pekat dan asetat anhidrit. Perubahan warna hijau-biru menunjukkan adanya steroid. (Harborne, 1996)

f. Uji Terpenoid

Ekstrak etanol daun mangga kasturi (Mangifera casturi Kosterm.) dicampur dengan asetat anhidrat ditambah $\mathrm{H} 2 \mathrm{SO} 4$ pekat dan asetat anhidrit. Perubahan warna warna merah ungu menunjukkan adanya triterpenoid. (Harborne, 1996)

g. Uji Kuinon

Ekstrak etanol daun mangga kasturi (Mangifera casturi Kosterm.) ditimbang sebanyak $0,05 \mathrm{~g}$ kemudian dilarutkan dalam $10 \mathrm{~mL}$ air suling panas sampai terbentuk larutan kemudian pada masing-masing larutan ekstrak ditambahkan beberapa tetes $\mathrm{NaOH} 1 \mathrm{~N}$, jika filtrat terbentuk warna merah menunjukkan adanya kuinon. (Harborne, 1996)

\section{Pengujian Antioksidan}

Ekstrak etanol mangga kasturi (Mangifera casturi Kosterm.) dibuat larutan baku induk (stok) sebesar 1000 ppm, dari larutan stok dibuat larutan uji dengan 5 seri konsentrasi. Selanjutnya, disiapkan larutan DPPH dengan konsentrasi 40 ppm. Larutan uji dengan berbagai seri konsentrasi sebanyak $2 \mathrm{~mL}$ ditambahkan dengan $2 \mathrm{~mL}$ larutan DPPH $40 \mathrm{ppm}$ dalam tabung reaksi bertutup lalu dihomogenkan dan didiamkan di tempat gelap pada suhu kamar selama 30 menit. Kemudian, dilakukan pengukuran absorbansinya pada panjang gelombang maksimum DPPH yaitu 450-600 nm menggunakan Spektrofotometer UVVis.

6. Inventarisasi Data

Semua data hasil dari penentuan kurva serapan dari DPPH 40 ppm, kurva serapan DPPH 40 ppm ditambah larutan seri konsentrasi vitamin C dan kurva serapan DPPH 40 ppm ditambah larutan seri konsentrasi ekstrak etanol dikumpulkan dan dibuat grafik perhitungan untuk menampilkan hasil yang diperoleh. Rumus perhitungan yang digunakan merupakan rumus umum dari absorbansi yaitu: 


$$
\% \text { inhibisi }=\frac{\text { Absorbansi Blanko - Absorbansi Sampel }}{\text { Absorbansi Blanko }} \times 100 \%
$$

Absorban kontrol (blanko) adalah serapan radikal DPPH dalam etanol pada panjang gelombang yang telah ditetapkan. Absorban bahan uji (sampel) adalah serapan radikal DPPH yang diberi perlakuan sampel dalam etanol pada panjang gelombang yang ditetapkan. (Prakash et al., 2001)

Selanjutnya dilakukan perhitungan $\mathrm{IC}_{50}$ melalui persamaan regresi linier yang menyatakan hubungan antara konsentrasi sampel uji (X) dengan persen aktivitas penangkap radikal rata-rata $(\mathrm{Y})$. Zat yang mempunyai aktivitas antioksidan tinggi akan mempunyai harga $\mathrm{IC}_{50}$ yang rendah.

\section{HASIL DAN PEMBAHASAN}

\section{Determinasi}

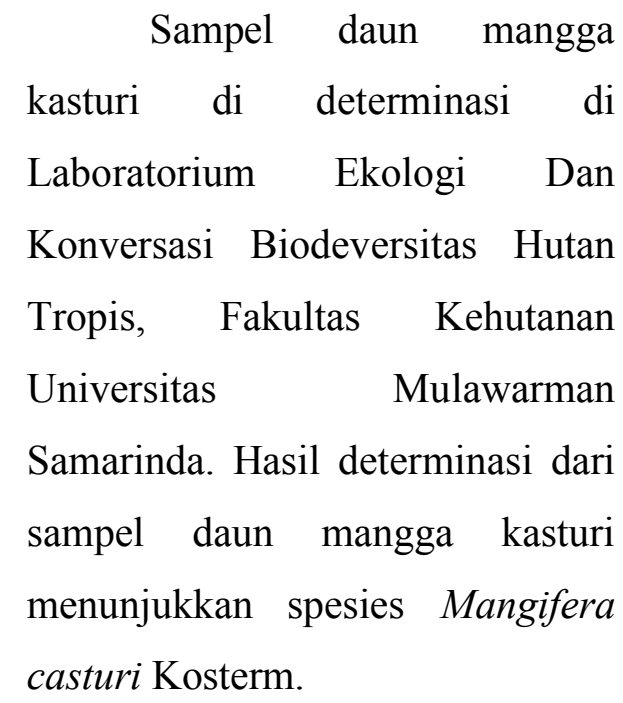

\section{Skrining fitokimia}

Skrining fitokimia adalah uji awal yang dilakukan untuk mengetahui kandungan metabolit sekunder yang terkandung dalam ekstrak etanol daun mangga kasturi.

Tabel 1. Hasil Skrining Fitokimia Daun Mangga Kasturi

No Uji Senyawa Hasil Uji

\section{Ekstrak Etanol}

\begin{tabular}{rll}
1 & Alkaloid & + \\
2 & Flavonoid & + \\
3 & Tanin & + \\
4 & Saponin & - \\
5 & Steroid & - \\
6 & Triterpenoid & - \\
7 & Kuinon & + \\
\cline { 2 - 3 } Keterangan & + (mengandung), - (tidak ada kandungan)
\end{tabular}


Berdasarkan hasil pengujian skrinning fitokimia ekstrak etanol daun mangga kasturi mengandung beberapa metabolit sekunder yaitu alkaloid, flavonoid, tanin dan kuinon. Alkaloid dapat berfungsi sebagai zat antioksidan hal ini didukung oleh penelitian uji antioksidan. (Hanani et al., 2005) Kandungan kimia yang diduga sebagai antioksidan adalah fenolik, flavonoid dan alkaloid. Fenolik, flavonoid dan alkaloid tersebar diberbagai bagian tumbuhan seperti akar, daun, kayu, buah, bunga dan biji. (Harborne, 1987)

Sebagian alkaloid memiliki kemampuan antioksidan, contohnya indol alkaloid seperti brusin dan strisin bila dilihat dari strukturnya dapat menangkal $1 \mathrm{O}_{2}$ serta kafein dapat bertindak sebagai peredam hidroksil radikal. Senyawa yang mengandung nitrogen dari tumbuhan berpotensi menghambat proses oksidatif. Turunan senyawa radikal dari senyawa amina memiliki tahap terminasi yang sangat lama dengan demikian mampu menghentikan reaksi rantai radikal secara efisien.
Flavonoid diketahui sebagai antioksidan yang baik karena mempunyai sedikitnya dua gugus hidroksil pada posisi otho dan para. Flavonoid dikatakan sebagai antioksidan karena dapat menangkap radikal bebas dengan membebaskan atom hidrogen dari gugus hidroksilnya. Flavonoid sebagai antioksidan memiliki potensi yang lebih tinggi sebagai obat antikanker dari pada vitamin dan mineral. (Lestari et al., 2019) Tanin mempunyai beberapa khasiat yaitu sebagai astringent, antidiare, antibakteri dan antioksidan. Tanin merupakan komponen zat organic yang sangat kompleks, terdiri dari senyawa fenolik yang sukar dipisahkan dan sukar mengkristal, mengendapkan protein dari larutannya dan bersenyawa dengan protein tersebut. (Malanggia et al., 2012)

Metabolit sekunder lainnya yang terdeteksi dalam penelitian ini adalah kuinon. Kuinon berasal dari oksidasi komponen fenol yang sesuai yaitu katekol (1,2 dihidroksibenzen) menghasilkam ortho-kuinon dan kuinol (1,4 dihidroksibenzen) menghasilkan 
para-kuinon, sehingga kuinon dapat terbentuk dari sistem fenol yang dihasilkan melalui jalur asetat atau siklamat. Senyawa naftokuinon diketahui bersifat sangat toksik, biasanya digunakan antara lain sebagai antimikroba dan antioksidan. (Kuntorini et al., 2010)

\section{Pengujian Aktivitas Antioksidan}

Peredaman warna DPPH terjadi karena adanya senyawa yang dapat memberikan radikal hidrogen kepada radikal DPPH sehingga tereduksi menjadi DPPH-H. (Prakash et al., 2011)

Tabel 2. Hasil Pengujian Antioksidan

\begin{tabular}{ccccc}
\hline Senyawa uji & Ppm & IC & persamaan & IC50 \\
& 25 & 15,38 & & \\
Ekstrak Etanol & 50 & 32,74 & $\mathrm{y}=0,5831 \mathrm{x}$ & \\
Daun Mangga & 75 & 43,40 & $+1,2444, \mathrm{r}=$ & 83,61 \\
Kasturi & 100 & 57,41 & 0,9925 & \\
& 125 & 75,94 & & \\
& 5 & 34,54 & & \\
Vitamin C & 7,5 & 48,74 & $\mathrm{y}=6,395 \mathrm{x}+$ & \\
& 10 & 71,64 & $3,5044 \mathrm{r}=$ & 7,27 \\
& 12,5 & 87 & 0,9789 & \\
\hline
\end{tabular}

Proses penangkapan radikal ini melalui mekanisme pengambilan atom hidrogen dari senyawa antioksidan oleh radikal bebas, sehingga radikal bebas menangkap suatu elektron dari antioksidan. Radikal bebas sintetik yang digunakan adalah DPPH. Senyawa DPPH bereaksi dengan senyawa antioksidan melalui pengambilan atom hidrogen dari senyawa antioksidan untuk mendapatkan pasangan elektron. (Power and Jackson, 2008)
Stres oksidatif dapat terjadi karena adanya ketidakseimbangan antara produksi radikal bebas dengan sistem pertahanan antioksidan di dalam tubuh. (Finaud, 2006) Radikal bebas DPPH bersifat peka terhadap cahaya, oksigen dan $\mathrm{pH}$, tetapi bersifat stabil dalam bentuk radikal sehingga memungkinkan untuk dilakukan pengukuran antioksidan. (Molyneux, 2004). Kandungan flavonoid dilaporkan memiliki aktivitas antioksidan, anti-diabetes, 
dan antikanker (Mohanraj dan

Sivasankar, 2014)

Pengukuran absorbansi

dilakukan dengan spektrofotometer

visibel pada panjang gelombang $517,4 \mathrm{~nm}$ dan berwarna ungu.

Peredaman radikal bebas oleh antioksidan terjadi ketika elektron tak berpasangan menjadi berpasangan dengan adanya sebuah donor hidrogen. Ekstrak etanol daun magga kasturi memiliki nilai $\mathrm{IC}_{50}$ 83,61 ppm di kategorikan sebagai antioksidan kuat sedangkan vitamin $\mathrm{C}$ sebagai pembanding sebesar 7,27 ppm merupakan antioksidan sangat kuat.

\section{KESIMPULAN}

Kesimpulan dari penelitian ini adalah :

1. Hasil pengujian skrinning fitokimia terhadap ekstrak etanol daun mangga kasturi (Mangifera casturi Kosterm.) megandung beberapa metabolit sekunder yaitu alkaloid, flavonoid, tanin dan kuinon.

2. Hasil pengujian aktivitas antioksidan dengan menggunakan metode DPPH (1,1-difenil-2pikrilhidrazil) menunjukkan bahwa ekstrak etanol daun mangga kasturi
(Mangifera casturi Kosterm.) memiliki aktivitas antioksidan dengan nilai $\mathrm{IC}_{50}$ sebesar 83,61 ppm dan termasuk dalam potensi antioksidan dengan kategori kuat.

\section{UCAPAN TERIMAKASIH}

Pada kesempatan ini, peneliti ingin mengucapkan terima kasih kepada Universitas Muhammadiyah Kalimantan Timur atas pendanaan pada penelitian ini yaitu pada Skim Penelitian Reguler Pemula (PERELA) sehingga terwujudnya penelitian ini.

\section{DAFTAR PUSTAKA}

Departemen Kesehatan Republik Indonesia. 1995. Farmakope Indonesia edisi III, Jakarta: Direktorat Jendral Pengawasan Obat dan makanan. Hal: 427-428. Finaud, J., Lac, G., dan Filaire, E. 2006. Oxidative Stress, Relationship with Exercise and Training. Journal Sports Med, 36(4): 327358.

Harborne, J.B. 1987. Metode Fitokimia

Penuntun Cara Modern Menganalisa Tumbuhan. Diterjemahkan oleh Padmawinata. K. Bandung: ITB-Press. Harborne, J.B. 1996. Metode Fitokimia. Edisi Kedua. 
Diterjemahkan oleh K.

Radmawinata dan I. Soediso.

Bandung: ITB Press.

Hanani, Endang. Abdul Mun ${ }^{\text {ee }}$ dan Ryany Sekarin. 2005. Identifikasi senyawa antioksidan Dalam spons callyspongia sp Dari kepulauan seribu. Majalah Ilmu Kefarmasian, Vol. II, No.3, Desember 2005, 127 - 133. ISSN : 1693-9883

Kuntorini, E. M., Astuti, M. D., Nugroho, L. H. 2010.”Struktur Anatomi dan Aktivitas Antioksidan Bulbus Bawang Dayak (Eleutherine americana Merr) Dari Daerah Kalimantan Selatan”. Penelitian Hayati. (16): 1-7.

Lestari, D., Kartika R., Marliana E., 2019. Antioxidant And Anticancer Activity Of Eleutherine bulbosa (Mill.) Urb on Leukemia cells $\mathrm{L}_{1210 .}$ Journal of Physics. Doi: $10.1088 / 1742-$ 6596/1277/1/012022.

Malanggia, L. P., Sangia, M. S., Paedonga, J.J.E. 2012. Penentuan Kandungan Tanin dan Uji Aktivitas Antioksidan Ekstrak Biji Buah Alpukat (Persea americana Mill.) Jurnal Mipa Unsrat Online, 1 (1): 5-10.
Mohanraj, R., dan Sivasankar, S. (2014):

Sweet Potato (Ipomoea batatas [L.]

Lam)-A valuable medicinal food: A review. Journal of Medicinal Food, 17(7), 733-741.

Molyneux, P. 2004. "The Use Of The Stable Free Radical Diphenylpicrylhydrazyl (DPPH) For Estimating Antioxidant Activity". Songklanakarin J. Sci. Technol. 26 (2) 211-219.

Nurmalasari, F., Ersam, T., dan Fatmawati, S. 2016. "Isolasi Senyawa Antioksidan Dari Kulit Batang Sonneratia ovata Backer". Jurnal Sains dan Seni ITS. Surabaya: Institut Teknologi 10 November. 5 (2) : 2337-3520.

Panjaitan, R. B. 2011.”Uji Toksisitas Akut Ekstrak Kulit Batang Pulasari (Alyxiae cortex) dengan Metode Brine Shrimp Lethality Test (BSLT)". Skripsi. Yogyakarta: Universitas Sanata Dharma.

Prakash, A., Rigelhof, F., and Miller, H.E. 2001. "Antioxidant Activity". Medallion Laboratories Analytical Progress. 10 (2).

Powers, S.K. dan Jackson, M.J. 2008. Exercise-Induced Oxidative Stress: Cellular Mechanisms and Impact on Muscle Force 
Production. Journal Physiol Rev, 88: 1243-1276.

Rohmatussolihat, 2009, Antioxidan, Penyelamat Sel-sel Tubuh Manusia, BioTrends, 4 (1), 5-9.

Rosydah K, Nurmuhaimina SA, Komari N, Astuti MD. 2010. Aktivitas
Antibakteri Fraksi Saponin dari Kulit Batang Tumbuhan Kasturi (Mangifera Casturi). Alchemy. Vol. 1 No. 2. : 53-103.

Sayuti, K., dan Yenrina, R. 2015. Antioksidan, Alami dan Sintetik. Padang: Universitas Andalas. 